乳房切除術後のリハビリテーションの効果

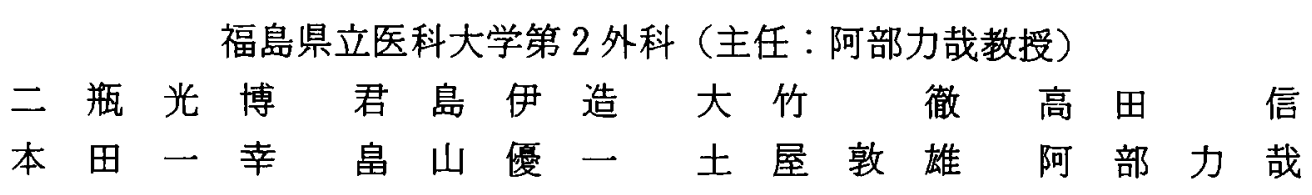

乳房切除術後のリハビリテーションの効果について, 患側肩関節可動域回復率と患側 上肢腫脹率の面から検討した。対象は皮虙切開を Stewart の横切開で行い, 皮店移植を せずに創閉鎖を施行した症例とした。方法は術前・術後 7 日目・退院時・術後 1 年目に 肩関節各運動の可動域と前腕 -上腕の周長を測定し, 可動域回復率之前腕 -上腕腫脹率 を算出した。 各運動の可動域回復率と術式, 胸筋神経の温存, 皮弁間張力との関係, お ょび腫脹率の推移について検討し以下の結果を得た。大・小胸筋切除の肩関節運動機能 に及ぼす影響は少なかった。術後 1 年目には全ての運動で術前の $90 \%$ 前後まで可動域が 回復した。胸筇神経の切断は大胸筋笳線維の萎縮を生じ, 肩関節運動機能を障害した。 皮弁間張力が $200 \mathrm{~g}$ 以内では, 張力は可動域回復率に影響しなかった。術後の周長増加の 最大は術後一年目にみられるが前腕・上腕ともに $3.5 \mathrm{~cm} て ゙$, 日常生活に支障を来す腫脹 はみられなかった。

索引用語 : 乳癌, 術後リハビリテーション, 肩関節機能障害, 胸筋神経温存, 浮腫

\section{緒言}

本邦において乳癌䍜患数は年々増加しており，近い 将来女性悪性腫瘍の第一位になると予測されている。 最近は一般雑誌に乳癌の記事が掲載されることも多 く, 乳癌に対する女性の関心は高い, 中でも働く女性 にとって, 手術後の患側上肢機能の障害程度と社会復 帰は切実な問題と言える。このような現況認識の下に, 教室では術後全例に理学療法士に上る患側上肢機能回 復訓練を中心とするリハビリテーションを施行してい る。リハビリテーションを受けない群は存在しないの で，䈣密な意味でリハビリテーションの効果の評価は 不可能であるが, 術式, 胸筋神経温存あるいは創部皮 弁間張力と肩関節可動域回復率の関係, おょび患側上 肢の浮腫について検討した。

\section{研究対象}

昭和62年以降教室で手術を施行した原発乳癌で, 以 下に示す適応条件を満たす症例を検討の対象とした。

1. 皮膚切開を Stewart の横切開で行った.

2. 皮庵移植を行わなかった。

3. 教室のスケジュールにしたがってリハビリテー

1991年 1 月 31 日受付 1991年 8 月 12 日採用
ションを施行した。

4. 術前・術後 7 日目・退院時・術後 1 年目にリハビ リテーションの効果について客観的評価を受けた。

5. 手術時年㱓が75歳以下であった。

以上の条件を満たした検討症例の内訳は, Patey 法 27例, Auchincloss 法10例, Ps 施行例を含む Standard 9 例であった。

\section{方 法}

教室のリハビリテーションのスケジュールを表 1 に 示す，入院後まず術前の評価を行らが，評価項目を表 2 に，検查表を図1に示す。初めに患側肩関節および 肘関節の自力による可動域の最大角度を測定した，次 に両側上肢の上腕骨内上顆上万 $10 \mathrm{~cm}$ と下方 $5 \mathrm{~cm}$ の位 置で，上腕と前腕の周長を測定した。ささらに，患側の 肩関節および时関節の徒手筋力と手術局所の皮唐触覚 検査を行った。この評価は術後 7 日目と退院時および 術後 1 年目にも行った。実際のリハビリテーションは 手術当日より開始した。まずマニュアルにしたがって 患側上肢の自力による機能回復訓練を開始するが，こ れは退院後も継続して行5ように指導した。術後 8 日 目からは理学療法士による患側肩関節と时関節の他動 的機能回復訓練と, 間欠波動型機械的マッサージ機で 
表1 リハビリテーション・スケジュール

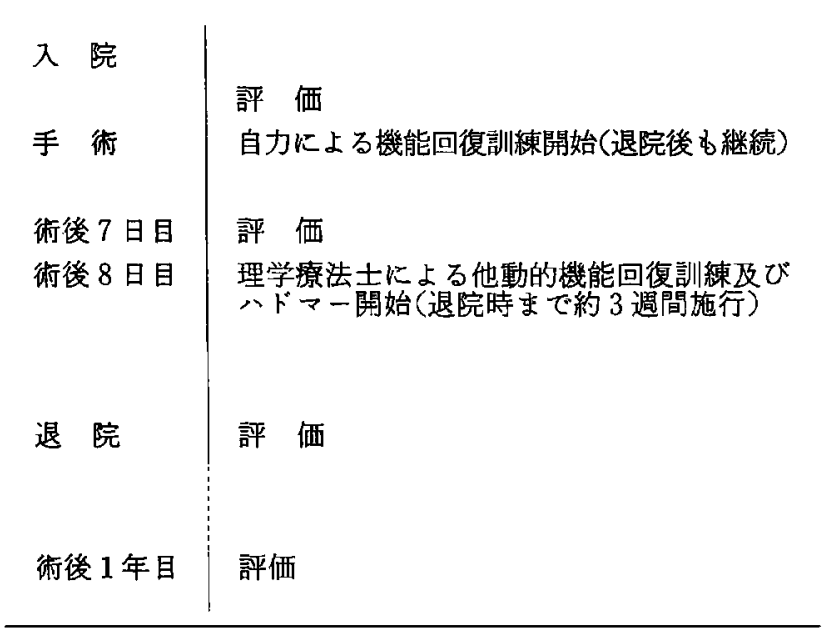

表 2 評価項目

\begin{tabular}{|c|c|}
\hline 1 & $\begin{array}{l}\text { 患側の肩・时関節可動域検査 } \\
\text { ※検査項目 } \\
\text { 肩関節 : 屈曲・伸展・外転・内転 } \\
\text { 外旋 } \cdot \text { 内旋・水平屈曲・水平伸展 } \\
\text { 时関節 : 屈曲・伸展 }\end{array}$ \\
\hline 2 & $\begin{array}{l}\text { 両側上肢の上腕・前腕周長測定 } \\
\text { ※測定部位 } \\
\text { 上腕：上腕骨内上顆上方 } 10 \mathrm{~cm} \\
\text { 前腕：上腕骨内上顆下方 } 5 \mathrm{~cm}\end{array}$ \\
\hline 3 & 患側の肩・时関節徒手筋力検查 \\
\hline 4 & 手術局所の皮或触覚検查 \\
\hline
\end{tabular}

あるハドマーによる患側上肢のマッサージを開始し， 退院時まで約 3 週間行った。肩関節可動域の障害度(術 後 7 日目）あるいは回復度（退院時, 術後 1 年目）の 判定は, 術前の自力による可動域の最大角度を 100 とし た時の比率（\%）で行った，可動域についての検討は 肩関節の 8 種類の運動の内から, 屈曲 - 伸展 - 外転 ・ 内旋・外旋の 5 種類の運動について行った，皮弁間張 力と肩関節可動域の回復率の関係については, 張力 （g）之可動域回復率（\%）の相関係数を求めて検討し た，患側上肢の腫脹率については，以下の式を用いて 術前の周長に対する増加周長の比率（\%)を算出した。 なおこの比率が負の場合は腫脹率を０\%とした。

尰脹率 $(\%)=\frac{\text { 術後周長一術前周長 }}{\text { 術前周長 }} \times 100$

$$
\text { 成 績 }
$$

1. 各術式別の肩関節可動域回復率の推移

1) 屈曲

肩関節の屈曲は術後 7 日目には，各術式とも術前の
欪者氏名

関 節 可 動 域 検 查 表

男女年合才右左

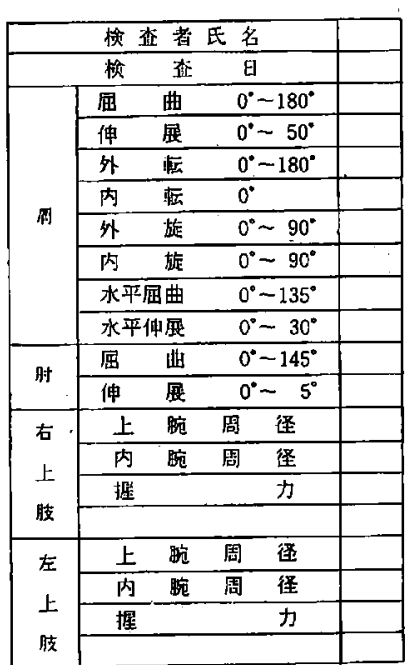

徒手筋力検 查 表

\begin{tabular}{|c|c|c|}
\hline \multirow{3}{*}{ 用 } & 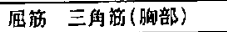 & $c 5,6$ \\
\hline & 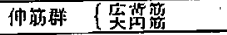 & $\begin{array}{l}C_{5}-8 \\
C_{5} .6 \\
\end{array}$ \\
\hline & 外在植 三色解 (中部) & $c 5,6$ \\
\hline 成 & 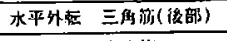 & c5.6 \\
\hline & 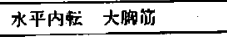 & $c 5-T_{1}$ \\
\hline tiri & 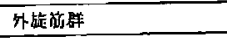 & c5, 6 \\
\hline & 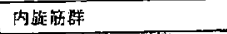 & $\mathrm{Cs}-\mathrm{Tl}$ \\
\hline & 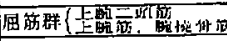 & $C 5,6$ \\
\hline & 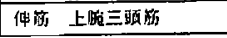 & 67.8 \\
\hline
\end{tabular}

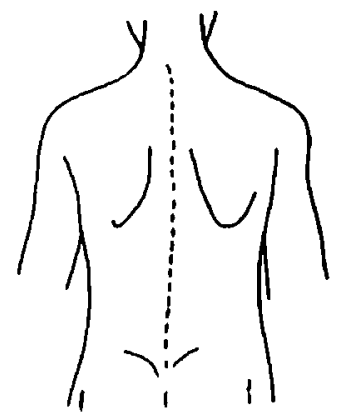

図 1 検查表

60\%前後まで可動域が障書された，退院時にはいずれ も80数\%まで回復し，それ以降も術後 1 年目までゆる やかに回復したが, 術式間で大差はみられなかった(図 2).7日目で最す障害の大きかったのはStandardで あったが, 術後 1 年目の評価で最も回復率の良かった のも Standard であった.

2) 伸展

肩関節の伸展は術後 7 日目にはStandardで術前の 70\%まで, Patey と Auchincloss で $80 \%$ 前後まで障害 された。退院時にはStandard と Patey で90\%すで， Auchincloss では98\%まで回復した，退院啳は回復率 の改善がなく，術後 1 年目の評価で各術式とも90\%前 後の回復率に留まり，Auchinclossではむしろ回復率 の低下が認められた（図 3 ).

3）外転

肩関節の外転は術後 7 日目にStandard で44\%ま で, Patey と Auchincloss で術前の50\%近くまで障害 され，障害の程度としては各運動中最も大さかった。 しかし，退院時にはStandard と Patey で75\%まで， Auchincloss で86\%まで回復し，その媵す緩徐に回復 


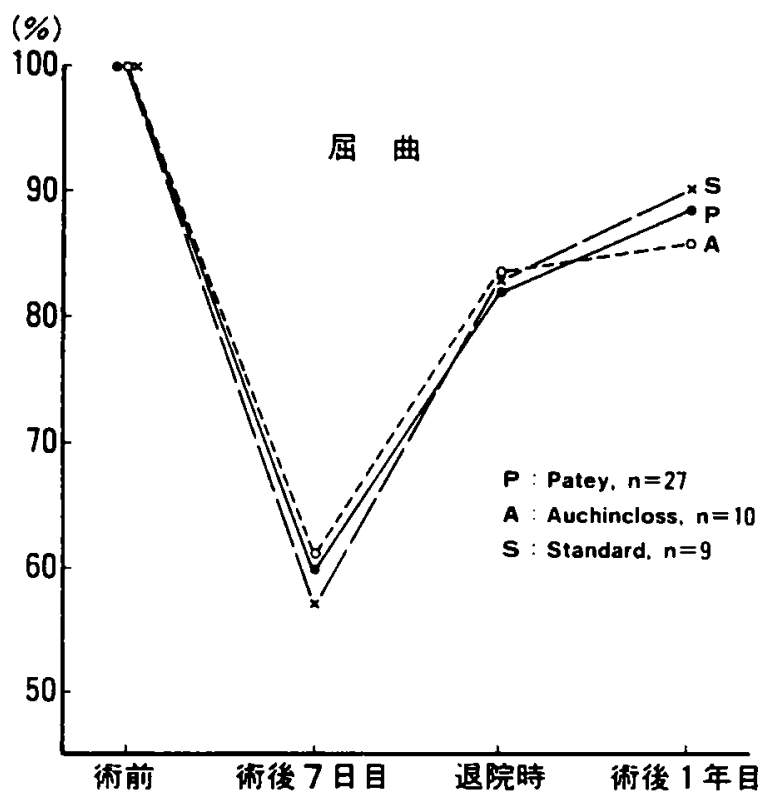

図2各術式別の扁関節可動域回復率の推移

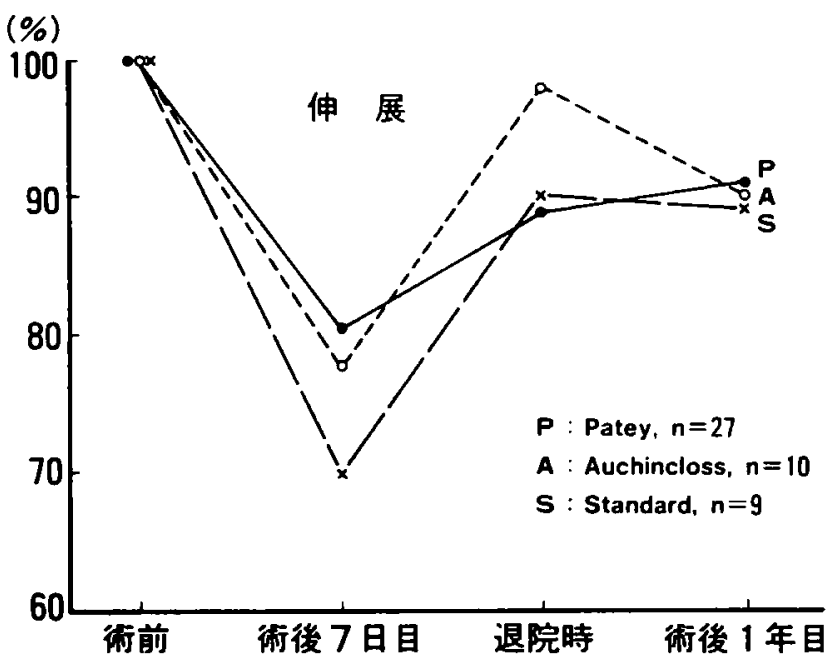

図 3 各術式別の局関節可钦域回復率の推移

し術後 1 年目には各術式とも $90 \%$ 近くまで回復した (図 4 ).

4) 外旋

肩関節の外旋は術後 7 日目にStandard で82\%程度 であったが, Pateyと Auchinclossでは70\%近くまで 障害された。退院時には各術式とも90\%前後まで回復 し，その後もStandard と Patey では緩徐な回復を見 たが, Auchincloss では87\%まで回復率が低下した(図 5 ).

\section{5）内旋}

肩関節の内旋は術後 7 日目に各術式の回復率に最も ぱらつきが認められた. Standard で92\%，Pateyで 82\%, Auchincloss で74\%と大胸筋を切除する Stan-

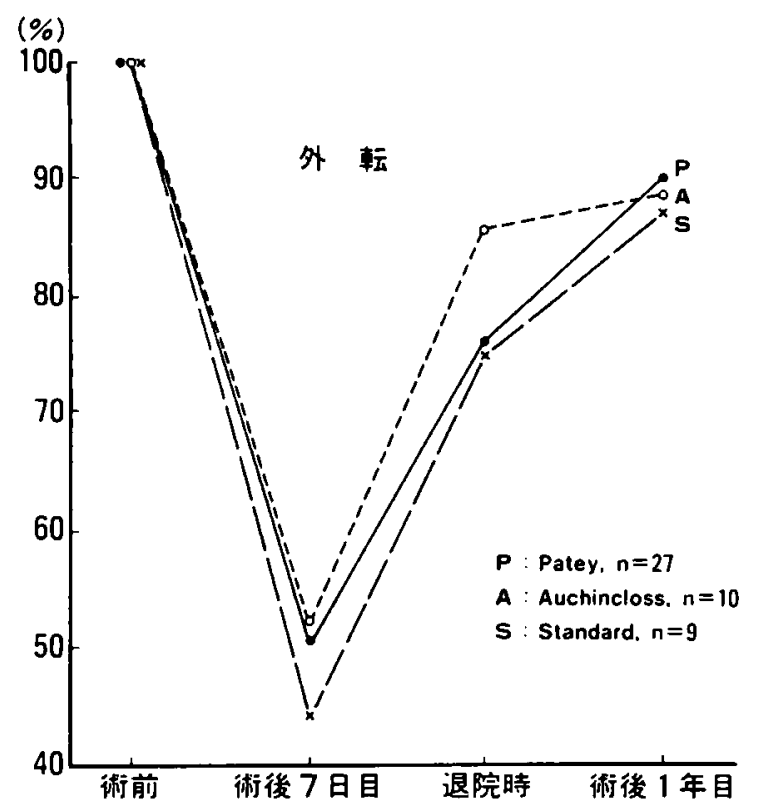

図 4 各術式別の肩関節可動域回復率の推移

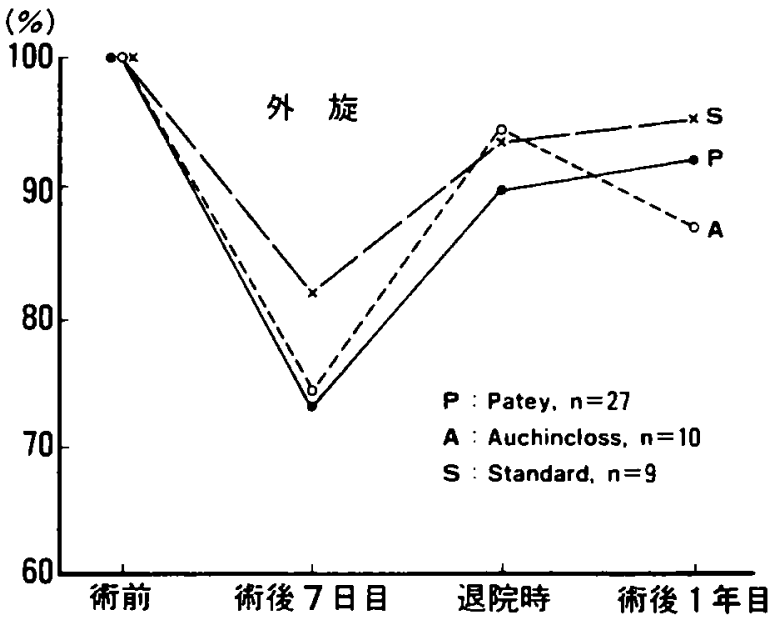

図 5 各術式別の肩関節可動域回復率の推移

dard で最も障害度が低く，大・小胸筋を温存する Auchinclossで最む障害された，Standardはその後に緩 除に障害が進行し，術後 1 年目には $90 \%$ 近くまで低下 した. PateyとAuchinclossは退院時にはそれぞれ $86 \%$ と6\%まで回復したが，その後，それ以上の回復 が得られず術後 1 年目の評価ではStandardより悪 かった（図6）。

2.Patey 法における胸筋神経と肩関筋可動域回復 率の関係

内側・中間・外側の 3 本の胸筋神経を温存した群と， 内側または中間のいずれか 1 本あるいは 2 本とも切断 した群の各肩関節運動の回復率を比較した。術後 7 日 目と退院時の評価では 2 群間に差は認められず，同程 


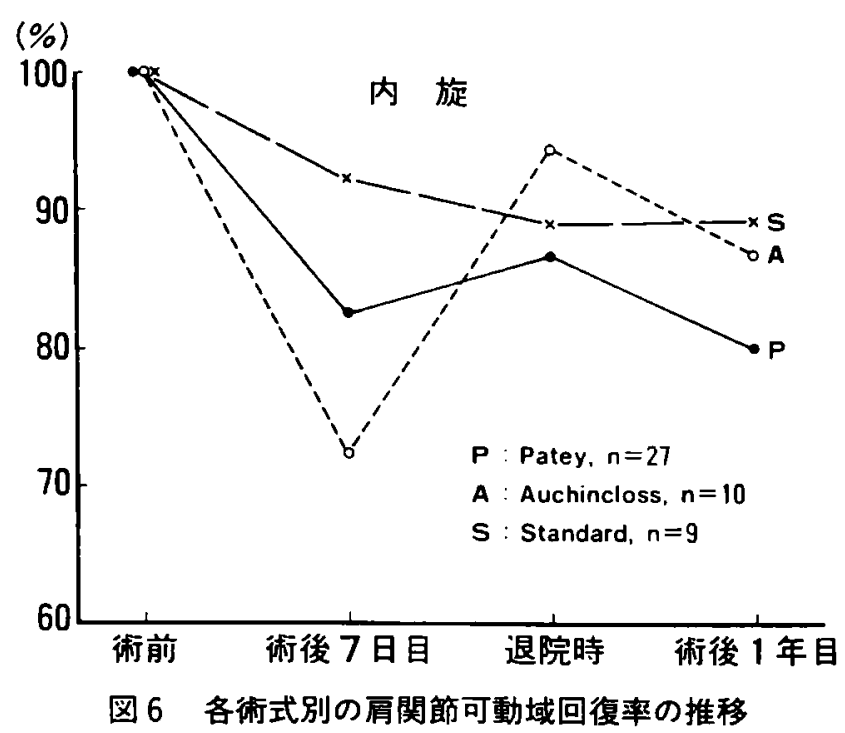

度の障害率と回復率であった。退院時は神経切断群の 回復率がさしろ良い傾向であった。しかし, 術後 1 年 目の評価では，いずれの運動も神経切断群の回復率が
神経温存群に比べ悪かった（図７）.

\section{3. 皮弁間張力と肩関節可動域回復率の関係}

Patey 法で皮弁間張力が $200 \mathrm{~g}$ 以内であった症例の， 屈曲と外転について皮弁間張力之可動域回復率の相関 係数を求めた。いずれの評価時期においても，両者間 に全く相関は認められなかった（図 8 ).

\section{Patey 法における患側上腕腫脹率}

術後 7 日目には上腕腫脹のある症例の割合が多い が，退院時には腫脹率 $0 \%$ 症例数が最も多かった。 術直後には一過性に上腕の腫脹がみられたが，退院時 には改善がみられた。術後 1 年目には腫脹率 $10 \%$ 以上 の症例が出現し，全体的に若千腫脹率の高い方へずれ る傾向がみられた(図 9)。周長増加の最大値は術後 1 年目の $3.5 \mathrm{~cm}$ であった。

\section{Patey 法における患側前腕腫脹率}

前腕の腫脹はいずれの時期でも上腕に比べて少な く, 腫脹率 $0 \%$ の症例数が最も多かった. 術後 1 年目 には腫脹率 $10 \%$ 以上の症例が出現し，全体的に腫脹率

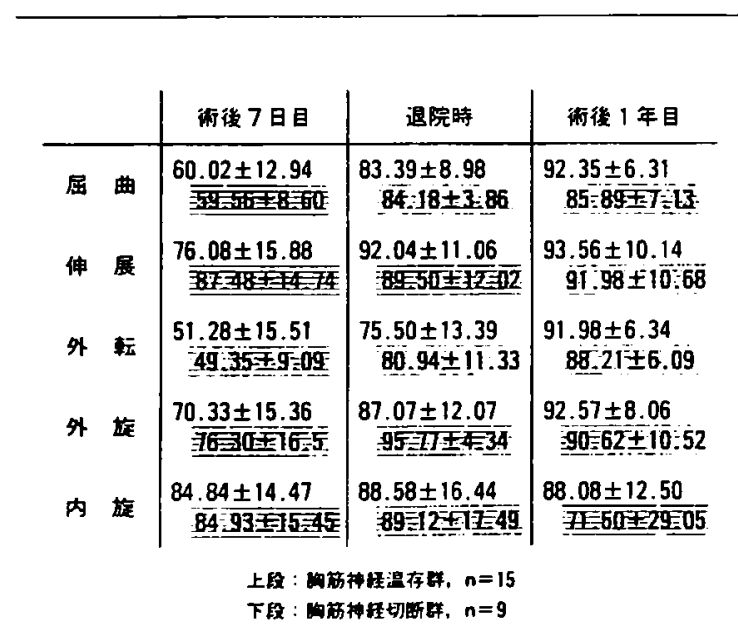

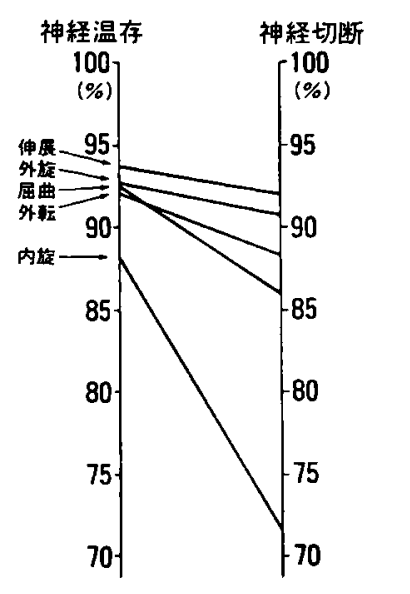

術後 1 年目の回復率(平均)の比较

図 7 Patey 法における胸筋神経と肩関節可動域回復率の関係

\begin{tabular}{|c|c|c|c|}
\hline & 術後 7日目 & 退 院 時 & 術後 1 年目 \\
\hline 屈曲 & $\begin{array}{c}Y=59.42+0.01 X \\
(r=0.0256, \quad \text { N.S. })\end{array}$ & $\begin{array}{c}Y=83.41+0.00 X \\
(r=0.0019, \text { N.S. })\end{array}$ & $\begin{array}{c}Y=82.61+0.01 X \\
(r=0.1017 \text {, N.S. })\end{array}$ \\
\hline 外 軩 & $\begin{array}{c}Y=49.49+0.01 X \\
(r=0.0443, \text { N.S. })\end{array}$ & 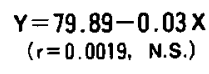 & $\begin{array}{c}Y=90.39+0.00 X \\
(r=0.0183, \text { N.S. })\end{array}$ \\
\hline & $x$ : 皮井问張力. & 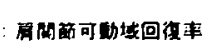 & \\
\hline
\end{tabular}

図 8 皮弁間張力と肩関節可動域回復率の関係 (Patey 法, $\mathrm{n}=24$ )
の高い方へずれがみられた(図10)。増加周長の最大値 は術後 1 年目の $3.5 \mathrm{~cm}$ であった。

$$
\text { 考 察 }
$$

現代の医療では生存率の改善のみならず, 術後の Quality of Life（QOL）の向上が要求されている. 近 年罹患者数が増加している乳癌では，術後の患側上肢 運動機能が QOL と深く関わっている，また働く女性 の多くなった昨今，術後早期社会復帰が求められてお り,この点からも術後の患側上肢の運動機能の早期回 


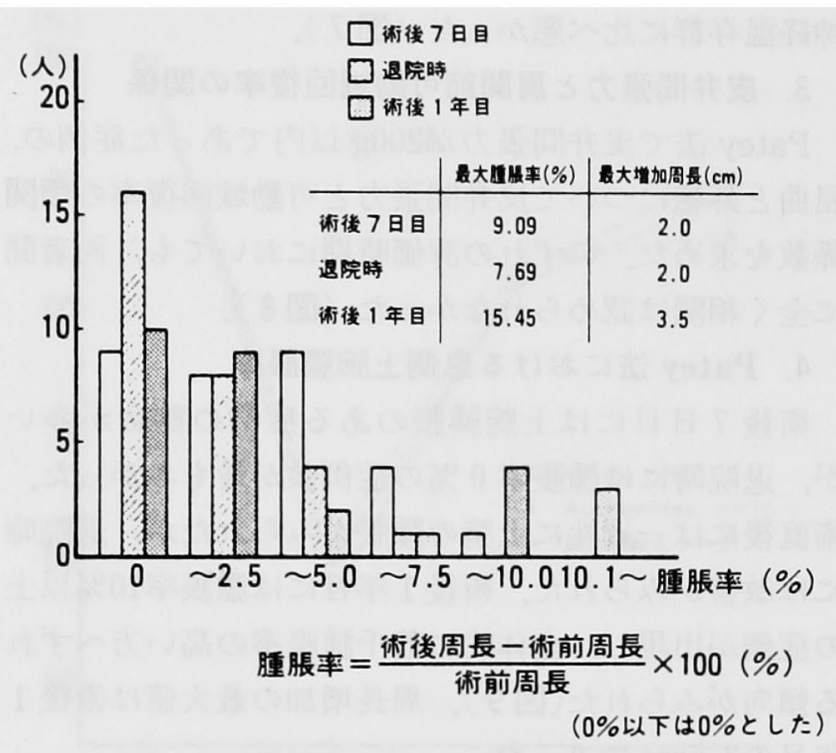

図 9 Patey 法における患側上腕腫脹率 $(n=27)$ （測 定部位：上腕骨内上顆上方 $10 \mathrm{~cm}$ )

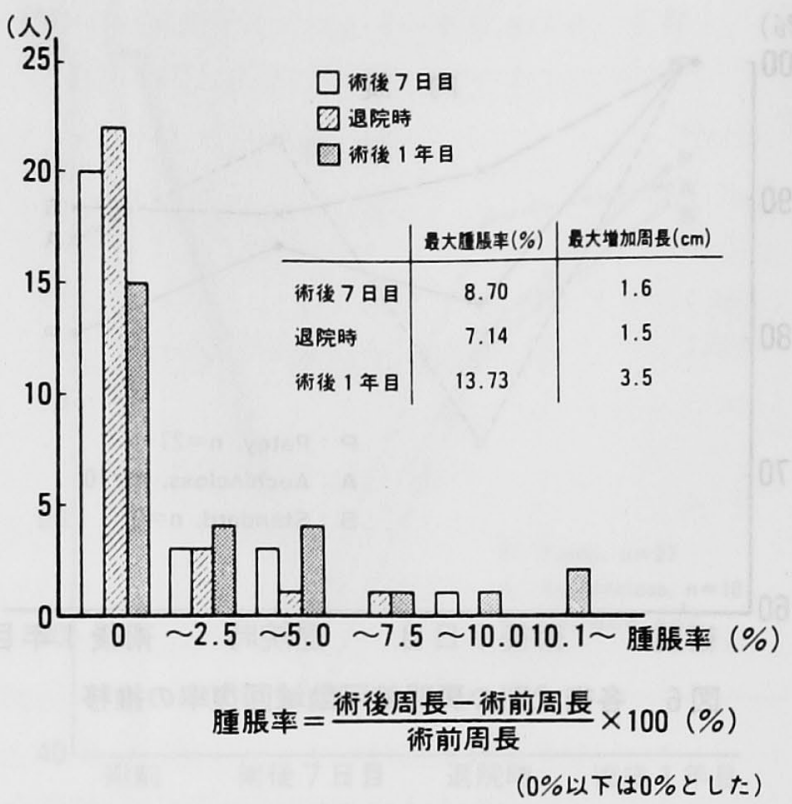

図10 Patey 法における患側前腕腫脹率 $(n=27) （$ 測 定部位：上腕骨内上顆下方 $5 \mathrm{~cm}$ )
復を目的とするリハビリテーションは重要である。乳 癌発生率の高い米国では早くよりこの問題に取り組 及, 理学療法的リハビリテーションと心身医学的リ八 ビリテーションを組み合わせた総合的なリハビリテー ションが行われてきた12). 本邦では理学療法的リハビ リテーションさえも行っていない施設が多く，心身医 学的リハビリテーションは積極的にはほとんど行われ ていない，教室では昭和62年より術後全例に理学療法 士による患側上肢の機能回復訓練を取り入れ 医学的には乳腺専門外来を設け患者との接触を密に行
い対話している。また教室で手術を受けた乳癌患者の 会を媒介として，心身医学的りハビリテーションの効 果を上げている. 本稿では, 理学療法的リハビリテー ションの効果を, 患側肩関節可動域の回復率と患側上 肢の腫脹率の面から検討した。教室のリハビリテー ションの特徵は，手術当日より自力による機能回復訓 練を開始し, 術後 8 日目からはそれと並行して理学療 法士による他動的な機能回復訓練を行うことにある.

表 3 は肩関節運動に関与する筋とその支配神経を示し

表 3 肩関節運動に閶与する筋(支配神経)

\begin{tabular}{|c|c|}
\hline 肩関節屈曲群 & 肩関節内転筋群 \\
\hline 1. 三角筋前部（腋窝神経） & 1. 三角筋前部之後部 (腋䆟神释) \\
\hline 2. 大胸筋鎖骨部（胸筋神経） & 2. 広背筋 (胸背神経) \\
\hline 3. 鳥口腕胆（筋皮神経） & 3. 大胸筋（胸筋神経） \\
\hline 4. 上腕二頭筋（筋皮神経） & 4. 上腕三頭筋長頭（㤬骨神経） \\
\hline 肩関節伸筋群 & 5. 烏口腕筋（筋皮神経） \\
\hline 1. 三角筇後部（腋窩神経） & 6. 大円筋 (肩甲下゙神経) \\
\hline 2. 上腕三頭筋長頭 (憢骨神経) & 肩関節外旋筋群 \\
\hline 3. 大円㘯（肩甲下神経） & 1. 小円䇨 (腋窝神経) \\
\hline 4. 広背筋 (胸背神経) & 2. 楝下筋（肩甲上神経） \\
\hline 肩関節外転筋群 & 3. 三角筋後部 (胸施神経) \\
\hline 1. 三角散外側部 (腋登神経) & 肩関節内旋筋群 \\
\hline \multirow[t]{5}{*}{ 2. 濑上筋（肩甲上神経） } & 1. 大円筋 (肩甲下神経) \\
\hline & 2. 厷背筋（胸背神経） \\
\hline & 3．肩甲下筇（肩甲下神経） \\
\hline & 4. 大胸筋 (胸筋神経) \\
\hline & 5. 三角筋前部（腋窩神経） \\
\hline
\end{tabular}


ているが，大胸筋が関与するのは屈曲，内転，内旋で ある。このらち屈曲に関与するのは大胸筋の鎖骨部で Standardでも温存される部分であり，大胸筋切除によ る屈曲障害は少ないと考えられる，内転に関しては術 後全く障害が認められず，今回の検討からは除外した。 したがって大胸筋切除に関わる運動は内旋のみという ことになる．小胸筋は肩関節運動に全く関与していな い.今回検討した 5 種類の運動の術後 7 日目の障害の 程度は, 外転, 屈曲, 外旋, 伸展, 内旋の順に大きかっ た。この順序は中山の報告" とほぼ一致している。術式 別に見ると, 術後 7 日目の運動障害度は内旋を除き Standard が若千大きい傾向を示したが術式間に有意 の差はみられず，大・小胸筋は肩関節運動障害にさほ ど関与していないことを支持している，他動的理学療 法開始後の肩関節可動域回復率の推移は, 術後 1 年目 まで改善がみられる運動と，退院時が最も良く術後 1 年目は若干悪化するパターンに分かれた。目常頻回に 行われる外転（水平挙上），屈曲（前方挙上）は術後最 る障害を受ける運動であるが，他動的理学療法を終了 した退院後も改善がみられる。しかし，一部を除きい ずれの運動も術後 1 年目には術前の $90 \%$ 近くまで回復 しており，日常生活上不自由するといった訴えはな かった、リハビリテーション非施行群は存在しないの で比較は不可能で断定はできないが，術後に理学療法 士による退院までの 3 週間程度の患側上肢機能回復訓 練は，早期の社会復㷌とQOL の向上といら点で有用 だったと考える。

教室の非定型的乳房切除術では内側・中間・外側の 3 本の胸筋神経をすべて温存することを原則としてい $~{ }^{6)}$. 胸筋神経を切断すると大胸筋の萎縮を来すと言 われている7が，この神経の切断が肩関節の運動にど の程度影響するかについての客観的なデータに基づく 報告は見られない.Patey 法で手術を施行した例で, 胸 筋神経と肩関節可動域回復率の関保をみると, 術後 1 年目の評価では全ての運動において, 神経切断群の回 復率は温存群に比べ劣っていた。両群間に統計的有意 差は認められず，また日常生活上肩関節運動で両群間 に特別の差はないが，客観的な数值としてこのような 差が出たということである。この差は神経の切断が退 院後除々に大胸筋外側部の筋線維萎縮を生し，肩関筋 運動障害を引き起こした結果と考えられる。1 年後に 肩関節可動域回復率の悪化がみられるのは, Standard よりも大胸筋を温存するPatey 法やAuchincloss 法 の非定型的乳房切除術に多いのは，この筇線維の萎縮
が原因と推定される。このことは非定型的乳房切除術 では胸筋神経を 3 本とも確実に温存することの大切さ を物語っている。

術後の患側肩関節運動障害を引き起こす大きな原因 の1つとして，創部の皮弁壊死による症痕收縮や運動 時の創部牽引痛が挙げられる 弁間張力と密接に関連すると考えられるが，教室では 創閉鎖時に最も張力の強いと思われる部位に $3-0$ ナ イロン手を片側皮弁に固定し，一方の皮弁にかけた糸 にはバネばかりをつけて創縁を互いに反対方向に引い て張力を測定している．測定は $0^{\circ}$ 内転位と $90^{\circ}$ 外転位 の 2 肢位で行っているが外転位では張力が増大する。 教室の君島らは両測定値間に $\mathrm{r}=0.87$ で有意の正の相 関があるが，内転位での張力が $100 \mathrm{~g}$ 以内の時の $90^{\circ}$ 外 転時の張力の増大に比へ，内転位で $100 か ら 200 \mathrm{~g}$ の時 の外転時の張力の増大は急速に大きくなると報告して いる9 . この関係は内転位の張力が $200 \mathrm{~g}$ を越光るとさ らに著明になり，外転時の張力が $500 \mathrm{~g}$ を越えることも しばしば認められるため，教室では内転位張力が $200 \mathrm{~g}$ を越える時は全層遊離皮膚移植を行っている。そこで Patey 法で皮虚移植を行っていない皮弁間張力 $200 \mathrm{~g}$ 以下の例で，皮弁間張力之肩関節可動域回復率の関係 を屈曲と外転運動で検討すると，全く相関関保は認め られなかった，皮弁間張力の増大は皮度切除に上る物 理的皮膚欠損の大きさによってもたらされるものであ る。したがって皮弁間張力の大きさに関わらず全例に 皮唐移植を行えば肩関節の運動障害を軽度に抑えるこ とができると考えられるが，全例に皮盾移植は必要な いと思われる。そこで創をさほど大きな緊張なしに一 期的に閉鎖できる皮并間張力 $200 \mathrm{~g}$ を，皮膚移植を考慮 する目安にすることは妥当と考えられる。

患側上肢の運動障害に関与する要因の 1 つに浮腫が あげられるが，浮腫は美容的にも問題でありQOLに 関わってくる，浮腫の原因は完全に解明されていない が，腋窝リンパ節郭清に起因するリンバ路の閉塞が原 因と考えられている ${ }^{10)}$ ．Patey 法に括ける患側前腕之 上腕の腫脹率をみると，退院時に腫脹のない症例が最 も多く，ハドマー等によるマッサージを中心としたり ハビリテーションが術後の浮腫防止に奏功したと考え られる。術後 1 年目には腫脹するものが出てくるが, 増加周長の最大值は $3.5 \mathrm{~cm}$ であり日常生活上で問題 はなかった。患側上肢の浮腫で問題になるのは, 術後 6 力月以降に発生する後期浮腫で，一度発生すると改 善は困難で良い治療法のないのが現状である，幸い今 
回の検討ではそのような例はなく，術当日よりの計画 的リハビリテーションが後期浮睡の防止にも効果があ るのかもしれない.

以上述べた他に，リハビリテーションの評価として 筋力の测定を行っているが，退院時にはStandard が 非定的乳房切除術に比べ若干筋力は劣っていたもの の, 術後 1 年目には術式に関わらず術前の筋力を回復 していた，大胸筋の奵除による肩関節の筋力の低下は 一過性のむのであることが分かった，局所皮虑の触覚 に関しては術後手術野局所の皮度の触覚鈍麻が生じる が，術後 1 年目の評価では周辺部に回復がみられる程 度である. 局所全体の触覚改善にはさらに数年を要す るよらであるが，完全な触覚の回復は期待できない.

\section{結語}

1. 乳癌術後の積極的なリハビリテーションは患側 上肢運動機能回復扎よび患側上肢の浮腫予防にとって 有用と考えられる。

2. 大・小胸筋の切除は局関節運動機能に大きな障害 をすたらさない。

3. 非定型的乳房切除術では内側・中間・外側の 3 本 の胸筋神経を全て温存することが重要であり，その切 断は大胸筋の筋線維萎縮を生じ, 肩関節の運動機能に 障害をもたらすと考えられる。

なお，この論文の要旨は第52回日本臨床外科医学会粉会 (東京)において発表した。

\section{文献}

1) Burdick D: Rehabilitation of the breast cancer patient. Cancer $36: 645-648,1975$

2) Scanlon EF, Feldman JL: Rehabilitation of the breast cancer patient. Semin Surg Oncol 4 : $268-273,1988$

3）野水 整, 土屋敦雄, 二瓶光博他：乳癌術後の上肢 機能低下の治療, 福島医誌 $38: 641-647,1988$

4) 二瓶光博, 阿部力哉, 八巻俊彦：㭪後リハビリテー ションの実際, 乳房切断, 外科 52 ：149-156, 1990

5）中山博輝：乳癌根治術後の上肢運動障害に対する リハビリテーション, 川崎医誌 9：378-387, 1983

6）阿部力哉：乳癌の手術, 福島医誌 $38: 1-8,1988$

7）久野敬二郎, 深見敦夫, 霞富士雄他：機能保存の癌 治㞠, 乳癌, 癌の臨 $30: 670-673,1984$

8）久保完治：根治術後の機能障害, 臨外 $30 ： 677$ $-682,1975$

9）君島伊造, 野水 整, 鈴木真一他：乳癌手術におけ る創傷治疹一第 2 報一，最新医 $44: 1983-1985$, 1989

10) Abe R: A study on the pathogenesis of postmastectomy lymphedema. Tohoku J Exep Med 118: $163-171,1976$

\title{
EFFECTS OF REHABILITATION IN POSTMASTECTOMY PERIOD
}

\author{
Mitsuhiro NIHEI, Izo KIMIJIMA, Tooru OTAKE, Makoto TAKADA, Kazuyuki HONDA, \\ Yuichi HATAKEYAMA, Atsuo TSUCHIYA and Rikiya ABE \\ Second Department of Surgery, Fukushima Medical College
}

Effects of rehabilitation after mastectomy were investigated for recovery rate of movable range of the affected shoulder joint and swelling rate of affected upper limb. Patients undergone Stewart's transverse incision and closed without skin graft were subjected. On a preoperative day, postoperative 7 th day, the day of discharge, and one year after operation, movable range of various exercises of the shoulder joint and circumference length of the forearm and upper arm were measured to calculate the recovery rate of movable range and swelling rate of upper limb. Correlations between the recovery rate and operative procedures, conservation of the pectoral nerve, and the between-flaps tension, as well as changes in the swelling rate were studied. As a result, there were little effects on impaired movement function of the shoulder joint due to resection of pectoralis major and/or minor muscle. In one year after mastectomy around $90 \%$ of movable range could be recovered in all kinds of exercise. Resection of the pectoral nerve produced atrophy of pectoralis major muscle and impaired the exercise function. If the between-flaps tensions were within $200 \mathrm{~g}$ or less, the tension gave no effect on the recovery rate of movable range. The maximum increase in the circumference length of the forearm and upper arm appered on the first year after mastectomy, which were both $3.5 \mathrm{~cm}$, and no remarkable swelling disturving daily activities of patients were observed. 